\title{
Pigura Filsofis Pendidikan Pembebasan (Membaca Ulang Sepenggal Pemikiran Paulo Freire)
}

\author{
ALIM HARUN PAMUNGKAS
}

Dosen Jurusan Pendidikan Luar Sekolah, Fakultas Ilmu Pendidikan Universitas Negeri Padang Jalan Prof. Dr. Hamka, Kampus UNP Air Tawar, Padang, (25131) Sumatera Barat, Indonesia Telepon : +62-822-3029-4393. Email : alimharun@fip.unp.ac.id, pamungkasd527@gmail.com

$\mathrm{P}$ aulo Freire adalah seorang pemikir pendidikan yang ternama pada abad ke-20 utamanya tentang pemikirannya mengenai pendidikan kritis (critical education) $[\mathrm{I}]$. Ia tak hanya dianggap sebagai pemuka pendidikan kritis, namun juga berperan penting dalam kampanye-kampanye literasi melek di Brasil pada era tengah tahun 1960-1965.

Penjara menjadi ujung dari kampanye literasi yang gencar dilakukannya. Ia selanjutnya dibebaskan dan diasingkan di Chili dan Jenewa, Swiss untuk beberapa tahun. Ia baru kembali ke Brazil pada tahun 1980. Seterusnya ia menjadi tokoh paling berperan dalam pembentukan kebijakan pendidikan hingga tahun 1997.

Pedagogy of the Oppressed, Pendidikan kaum tertindas, adalah sebuah karya kritik monumentalnya yang memengaruhi banyak kelompok intelektual pendidikan di Amerika Serikat dan banyak negara di dunia. Menurutnya, tak banyak kaum intelektual yang memiliki kelenturan teoritik dalam memandang persoalan pendidikan. Atau, keberanian moral dalam berkontribusi terhadap persoalan pendidikan.

Cara pandang pendidik yang konservatif, kecanduan metode, keterjebakan terhadap instrumentasi pengajaran, atau pengelolaan pendidikan yang tak visioner, menurutnya adalah penghambat utama terciptanya kehidupan masyarakat yang demokratis.

Arus kapitalisme dan neoliberal secara masiv mendorong pendidikan tak lebih sebagai penyedia tenaga terampil demi kepentingan industrialisasi. Pendidikan seperti kehilangan pusara keberadaban dan kebermoralan yang menjadi inti.

Kampanye yang dilakukan Freire secara perlahan berhasil menarik simpati banyak pihak untuk bekerjasama. Utamanya untuk mengembalikan pendidikan kepada inti utamanya. Yaitu kesadaran. Kesadaran adalah hasil yang hendak dicapai. Pembebasan adalah praktek yang dilakukan. Demikian kiranya, ringkas kata tentang pandangan dan upaya Freire.

Pendidik tak lagi pantas dipahami sebagai teknisi belaka yang menjalankan 'manual' pengajaran dengan perangkat instrumentasi pendidikan semata. Praktek yang hanya akan menjadikan peserta didik (warga belajar) sebagai makhluk yang terjinakkan, bukan sebagai manusia yang tersadarkan. Praktek yang tak berbasis pada manusia sebagai subyek, melainkan sebagai obyek.

Matinya tradisi berpikir kritis dan kebebasan ekspresi. Terlalu banyak ruang kelas pada semua tingkatan pendidikan tak ubah seperti 'zona mati'. Ruang kelas seakan lemah dan sarat dengan intervensi korporasi.
Kecepatan waktu lulus dan perebutan skor tertinggi merupakan wajah yang tak lagi asing pada institusi pendidikan [2].

Kondisi ini menjadikan pendidik tak lagi bertanya tentang kesiapan institusi pendidikan dalam menyiapkan peserta didik (warga belajar) menjadi warga negara yang terinformasi dan penuh imajinasi sebagai warga sipil. Atau bahkan memiliki 'self-reflective' tentang isu-isu umum dan perhatian terhadap realitas di mana mereka hidup.

Dikutip dari Stanley Aronowitz sebagai berikut.

\begin{abstract}
"Few of even the so-called educators ask the question: What matters beyond the reading, writing, and numeracy that are presumably taught in the elementary and secondary grades? The old question of what a kid needs to become an informed 'citizen' capable of participating in making the large and small public decisions that affect the larger world as well as everyday life receives honorable mention but not serious consideration. These unasked questions are symptoms of a new regime of educational expectations that privileges job readiness above any other educational values" [3].
\end{abstract}

"Beberapa pendidik mengajukan pertanyaan: apakah hal yang lebih terpenting dari membaca, menulis, dan berhitung yang diajarkan pada tingkat sekolah dasar dan menengah? Pertanyaan kuno tentang apa yang dibutuhkan anak-anak untuk menjadi warga negara yang terinformasi, anak-anak yang memiliki kecakapan untuk berpartisipasi dalam pembuatan keputusan publik, baik pada skala kecil atau pun besar yang berpengaruh luas dalam kehidupan. Hal tersebut merupakan pertanyaan yang tak pernah ditanyakan sebagai penanda dari sebuah rezim baru masa depan pendidikan yang menyatakan bahwa kesiapan kerja adalah di atas banyak nilai pendidikan lainnya”.

Freire percaya bahwa pendidikan merupakan proyek nyata politik dan pembebasan. Prakteknya, pengajaran harus memasilitasi peserta didik (warga belajar) untuk merefleksi diri, mengelola kehidupan pada semua tingkatannya. Keaksaraan (baca: calistung) tak sekadar persiapan menjadi 'buruh'. Tetapi persiapan untuk kemampuan mengelola kehidupan (menentukan nasib sendiri).

Terbukanya pilihan yang tak semata ditentukan oleh arus pasar kerja serta kegilaan label sosial sebagai produk utama persekolahan, hanya bisa dibongkar jika terpenuhinya tiga syarat. Pertama, refleksi diri. Pendidikan berhasil menunjukkan keberadaan nyata peserta didik (warga belajar) tentang posisinya dalam struktur politik, ekonomi, dan budaya. Kesadasaran ini akan membantu peserta didik (warga belajar) dalam menyusun target partisipasinya dalam masyarakat. Kedua, kritis. Pendidikan berhasil membantu peserta didik (warga belajar) untuk peduli. Kepedulian adalah kekuatan 
pembentuk kesadaran dalam keterlibatan di masayarakat. Ketiga, jika pendidikan telah berhasil membantu peserta didik (warga belajar) untuk menghasilkan kehidupan yang baru (toleran, peduli lingkungan, dan sebagainya) [4].

Menurut Freire, pengajaran tak hanya metode, melainkan praktek politik dan moral. Pengajaran harus mampu menyediakan pengetahuan, keterampilan dan hubungan sosial yang memungkinkan peserta didik (warga belajar) memperluas peluang warga negara yang kritis. Berpikir kritis menurut Freire dipahami dalam konstruksi berikut.

Pertama, bukanlah pelajaran yang dapat diukur melalui perangkat tes. Kedua, kemampuan berpikir kritis akan menjadi penentu nasib bagi masing-masing peserta didik (warga belajar) dan nasib dari partisipasi masyarakat dalam pembangunan. Ketiga, berpikir kritis bukanlah tentang reproduksi pengetahuan masa lalu dan sekarang, namun cara berpikir yang melampaui kekinian.

Theodor Adorno menangkap semangat gagasan berpikir kritis Freire sebagai berikut.

"Thinking is not the intellectual reproduction of what already exists anyway. As long as it doesn't break off, thinking has a secure hold on possibility. Its insatiable aspect, its aversion to being quickly and easily satisfied, refuses the foolish wisdom of resignation.... Open thinking points beyond itself".

"berpikir bukanlah reproduksi intelektual tentang apa yang sudah ada. Selama itu tidak mematahkan, berpikir telah menyelamatkan beragam kemungkinan. Berpikir adalah aspek yang tak dapat dipuaskan, yang menjadikan untuk cepat bosan dan mudah merasa puas, berpikir merupakan bentuk penolakan terhadap tradisi tolol. Buka pikiran lebih luas di luar pemikiran itu sendiri". [5]

Pendidikan telah mengalami degradasi makna. Pendidikan harus mampu melepaskan diri dari keterjebakan pada pengetahuan dan keterampilan semata. Melainkan pendidikan harus mampu menuju titik barunya, yaitu lahirnya pemikiran kritis, ajaran tentang kebebasan dan sosial tanggung jawab dari setiap peserta didik (warga belajar).

Freire percaya bahwa esensi dari pendidikan kritis adalah kepercayaan bahwa kehidupan manusia itu dikondisikan (oleh manusia), dan tidak ditentukan (oleh Tuhan). Maka dari itu, kebutuhan manusia pun tak hanya cukup dengan membaca dunia secara kritis, namun juga terlibat dalam tatanan sosial yang lebih besar sebagai bagian dari tanggung jawab warga negara.

Menurut Freire, pendidikan tak dapat dilepaskan dari pusara politik dan kekuasaan. Maka, pendidikan haruslah menanamkan kesadaran. Pendidikan tak sepantasnya dijadikan sebagai alat kekuasaan dan alat pencarian keuntungan yang kapitalistik. Doktrin pendidikan kritis yang dikampanyekan Freire, berusaha mengarahkan peserta didik (warga belajar) untuk menjadi subyek dalam relasi ekonomi (produksi, distribusi, dan konsumsi), dan bukan sebagai obyek.

Identitas, nilai-nilai, dan keinginan yang dibentuk di dalam kelas menurut Freire adalah dasar politik.
Pendidikan kritis berarti: (I) membekali peserta didik (warga belajar) dari sekadar keterampilan menjadi 'selfreflective'; dan (2) menyiapkan peserta didik (warga belajar) dari sekadar memahami pengetahuan secara tekstual menjadi pemahaman tentang nilai moral dan tanggung jawab terhadap lingkungan di mana mereka berada.

Freire menyadari bahwa pendidikan kritis merupakan ancaman bagi elite penguasa dan kelompok pemuka agama (ekstrimis) yang terbiasa dengan 'definisi tunggal'. Menurutnya, tugas berat adalah dengan membongkar definisi terpusat tersebut untuk melahirkan tafsir baru yang dapat menjadi jembatan antara definisi dengan kenyataan dan perubahan sosial dalam keseharian.

Pendidikan kritis membuka ruang dialog yang sangat damai antara pengetahuan 'kelas' dengan kenyataan. Selanjutnya, inilah yang dipahami sebagai sisi paling demokratis dalam pendidikan secara esensial. Karena pendidikan tak hanya tentang 'tahu', namun juga tentang 'kesadaran'. Dengan demikian, pendidikan akan menjadi pembongkar dari kerumitan pengetahuan yang dibangun oleh politik dan dicatat sejarah [6].

Sejarah dalam pengertian ini bergerak sebagai narasi terbuka untuk terjadinya sebuah proses dialog kritis tentang teks yang telah didefenisikan sebelumnya. Pendidikan bertugas menyediakan kondisi yang menumbuhkan keraguan (skepticism) terus menerus [7].

Menurut Freire, semua bentuk pendidikan mewakili cara tertentu tentang pemahaman masyarakat akan realitasnya. Pendidikan kritis tidak seperti umumnya yang diparktekkan dalam persekolahan. Dalam pendidikan kritis, tugas mendasar pendidik adalah untuk memastikan bahwa masa depan adalah menunju pada dunia yang lebih berkeadilan (baca: setara) [8].

\section{DAFTAR BACAAN}

[I] One of the best sources on the life and work of Paulo Freire is Peter Mayo, "Liberating Praxis: Freire's Legacy for Radical Education and Politics" (Rotterdam: Sense Publishers, 2008). Two of the best translators of Freire's work to the American context are Donaldo Macedo, "Literacies of Power" (Boulder: Westview, 1994) and Ira Shor, "Freire for the Classroom" (Portsmouth, New Hampshire: Boynton/Cook, 1987).

[2] On the issue of containment and the pedagogy of punishment, see: Jenny Fisher, "The Walking Wounded: The Crisis of Youth, School Violence, and Precarious Pedagogy, Review of Education, Cultural Studies, and Pedagogy" (in press).

[3] Stanley Aronowitz, "Against Schooling: For an Education That Matters," (Boulder, Colorado: Paradigm Publishers, 2008), p. xii.

[4] Stanley Aronowitz, "Forward," "Critical Pedagogy in Uncertain Times: Hope and Possibilities," ed. Sheila L. Macrine, (New York, New York, Palgrave MacMillan, 2009) pp. ix.

[5] Theodor Adorno, "Education after Auschwitz," "Critical Models: Interventions and Catchwords" (New York: Columbia University Press, 1998), p. 291-292.

[6] Edward Said, "Reflections on Exile and Other Essays" (Cambridge: Harvard University Press, 200I), p. I4I.

[7] Ibid, Edward Said, Reflections on Exile and Other Essays, p. 50I.

[8] Stanley Aronowitz, "Introduction," in "Paulo Freire, Pedagogy of Freedom" (Boulder: Rowman and Littlefield, I998), pp. I0 II. 